\title{
STATUS KESEHATAN IKAN SIDAT (Anguilla sp.) PADA PERAIRAN UMUM DAN WADAH PEMELIHARAAN SEMENTARA
}

\author{
Agung Cahyo Setyawan"\#, Sukenda" , dan Sri Nuryati" \\ ") Mahasiswa Ilmu Akuakultur, Pascasarjana Institut Pertanian Bogor \\ ") Departemen Budidaya Perairan, Fakultas Perikanan dan Ilmu Kelautan, Institut Pertanian Bogor \\ (Naskah diterima: 11 April 2014; Revisi final: 31 Oktober 2014, Disetujui publikasi: 11 Maret 2015)
}

\begin{abstract}
ABSTRAK
Status kesehatan ikan sidat (Anguilla sp.) telah dianalisis untuk menunjukkan terjadinya penurunan stok karena infeksi patogen dan penangkapan benih berlebihan untuk budidaya. Di Indonesia, ketiadaan standar penangkapan, pemeliharaan dan budidaya menyebabkan terjadinya penurunan kualitas dan kuantitas produksi ikan sidat. Penelitian ini dilakukan untuk mengevaluasi status kesehatan ikan sidat di perairan Indonesia dengan sampel dari Kabupaten Banyumas dan Cilacap, Jawa Tengah. Sampling dilakukan pada awal musim penghujan, yaitu bulan September hingga November 2012. Sebanyak 113 ekor ikan sidat ditangkap dan dianalisis dalam penelitian ini, dengan perincian 57 ekor diamati langsung setelah ditangkap dan 56 ekor diamati setelah dipelihara selama 10 hari oleh pengepul. Pengamatan dilakukan dengan metode observasi langsung menggunakan mikroskop untuk parasit, kit API 20NE (Biomeureux ${ }^{\circledR}$ ) untuk bakteri dan pewarnaan standar haematoxylin-eosin untuk histopatologi. Terdapat empat jenis parasit (Nematoda: Camallanidae dan Anguillicoloides; Platyhelminthes: Monogenea dan Digenea) dan lima bakteri (Aeromonas hydrophylla, Pseudomonas luteola, Vibrio fluvialis, Aeromonas sobria, dan Aeromonas caviae) dari sampel ikan sidat dalam penelitian ini. Tidak terdapat perbedaan dalam komposisi patogen, namun terjadi perubahan dalam kondisi histopatologi sehingga pemeliharaan sementara oleh pengepul sebelum ikan sidat dibudidayakan memiliki potensi menurunkan kualitas benih untuk budidaya.
\end{abstract}

KATA KUNCI: ikan sidat (Anguilla sp.), status kesehatan, parasit, bakteri, histopatologi

ABSTRACT: Health status of eel (Anguilla sp.) from natural and temporary rearing. By: Agung Cahyo Setyawan, Sukenda, and Sri Nuryati

Health status of eel (Anguilla sp.) has been analyzed to show a serious decline in stock because of overfishing and pathogen infection. Neither lack of culture technique nor standard rearing and catching influenced the quality and quantity of eel production in Indonesia. In order to get early information about health status from eel catched in Indonesia, this research was held using samples from Cilacap and Banyumas Residence in Central Java. Samples were taken during early rainy season in September until November 2012. Total of 113 eels were catched and analyzed in this research: 57 eels quickly analyzed after hauling, while 56 eels analyzed after 10 days rearing in traditional fisherman. Parasite was observed using direct microscopy technique, kit API 20NE (Biomeureux ${ }^{\circledR}$ ) used to bacteria identification and standard HE technique used to analyze histopathology of eel. There were four parasites (Nematoda: Camallanidae and Anguillicoloides; Platyhelminthes: Monogenea and Digenea) and five bacteria (Aeromonas hydrophylla, Pseudomonas luteola, Vibrio fluvialis, Aeromonas sobria, and Aeromonas caviae) founded. No difference in pathogen composition but haematological and histopathological disorder detected in both sample group. Therefore, temporary rearing did not straighly reduce the health status of eel, but influence the eel quality which would treatening eel culture.

KEYWORDS: eel (Anguilla sp.), health status, parasite, bacteria, histopathology

\# Korespondensi: Mahasiswa Ilmu Akuakultur, Pascasarjana

Institut Pertanian Bogor. Jl. Lingkar Akademik, Kampus IPB

Dramaga, Bogor 16680. Tel.: + (0251) 622642

E-mail: kenfajri@yahoo.com ; agung.cahyo@gmail.com 


\section{PENDAHULUAN}

Informasi status kesehatan pada ikan budidaya telah banyak dijadikan acuan untuk perbaikan metode budidaya dan penanggulangan serangan penyakit, sedangkan informasi pada ikan liar digunakan untuk analisis populasi dan stok. Pedersen et al. (2008) telah melakukan pengamatan status kesehatan ikan rainbow trout (Oncorhynchus mykiss Walbaum) selama periode tertentu pada kegiatan budidaya di Denmark sebagai trigger penerapan vaksinasi untuk pencegahan infeksi beberapa jenis bakteri. Esteve \& Alcaide (2009) melaporkan bahwa struktur populasi, kondisi morfologi, dan fisiologis ikan sidat Eropa (Anguilla anguilla) terganggu karena infeksi berbagai jenis patogen.

Perkembangan informasi status kesehatan untuk ikan sidat Eropa menunjukkan bahwa stok, populasi dan produksi dari budidaya ikan ini mengalami gangguan serius akibat infeksi berbagai jenis patogen. Penurunan kemampuan berenang silver eel akibat infeksi Anguillicola crassus pada gelembung renangnya (Palstra et al., 2007), adanya hemorhagi dan nekrosis hingga hiperplasia, hipertrofidan kongesti pada organ tubuh akibat infeksi (Abdelmonem et al., 2010; Haenen et al., 2010) dipastikan menyebabkan gangguan pada ikan sidat secara morfologi dan fisiologis. Hal ini seharusnya menjadi perhatian serius karena ikan sidat telah menjadi salah satu komoditas perikanan penting yang hingga saat ini belum diketahui teknik budidayanya secara utuh (mengandalkan benih hasil tangkapan).

Kondisi benih hasil tangkapan sulit untuk dibuat standar karena terdapat banyak faktor berpengaruh. Fluktuasi temperatur selama migrasi telah dilaporkan oleh Haenen et al. (2010) menyebabkan peningkatan prevalensi patogen pada ikan sidat. Perubahan salinitas selama migrasi juga cukup signifikan memberikan pengaruh terhadap kondisi fisiologis ikan sidat. Briones et al. (2007) bahkan menyebutkan bahwa salinitas merupakan faktor penting yang menentukan preferensi habitat ikan sidat untuk tumbuh menjadi dewasa. Keragaman pengaruh lingkungan tersebut akan berkorelasi dengan pengaruh penanganan dan pemeliharaan sejak benih ikan sidat ditangkap hingga dijual kembali untuk dibesarkan dalam kolam budidaya. Ketiadaan standar baku tentang teknik penangkapan dan pemeliharaan benih ikan sidat hasil tangkapan menjadikan pembudidaya seringkali menghadapi kondisi benih ikan sidat yang sangat beragam.

Penangkap ikan sidat di Indonesia umumnya menampung hasil tangkapannya selama 1-2 minggu sebelum dibeli oleh pembudidaya atau pengekspor. Pemeliharaan dengan wadah dari terpal, kepadatan tinggi, tanpa manipulasi lingkungan dan pemberian pakan merupakan keadaan umum pemeliharaan dalam periode ini. Kondisi tersebut menurut Rodriguez et al. (2005) dapat menyebabkan perubahan kondisi histopatologi sehingga mengubah status kesehatan ikan sidat secara umum. Penelitian ini dilakukan untuk mengevaluasi status kesehatan benih ikan sidat yang baru ditangkap dari alam dan setelah dipelihara selama 10 hari pada wadah penampungan sementara oleh pengepul. Informasi yang diperoleh sangat berguna untuk acuan perbaikan metode penangkapan dan pemeliharaan sementara, penetapan standar status kesehatan ikan sidat untuk budidaya dan penyusunan metode budidaya terbaik sesuai kondisi benih ikan sidat.

\section{BAHAN DAN METODE}

\section{Pengadaan Sampel}

Penelitian ini dilakukan dengan metode eksploratif menggunakan teknik purposive sampling di mana sampel diambil dari tempat dengan ketersediaan benih ikan sidat sesuai ukuran yang telah ditentukan (fingerling). Pengambilan sampel dilakukan di wilayah Kabupaten Cilacap dan Banyumas, Jawa Tengah pada bulan September hingga November 2012 (Tabel 1). Lokasi pengampilan sampel merupakan daerah yang berada di sepanjang aliran Sungai Serayu, Jawa Tengah (Gambar 1).

Tabel 1. Waktu dan tempat pengambilan sampel

Table 1. Sampling time and places

\begin{tabular}{lll}
\hline \multirow{2}{*}{ Waktu (Time) } & \multicolumn{2}{c}{ Lokasi (Places) } \\
\cline { 2 - 3 } & \multicolumn{1}{c}{ Penangkapan (Catching) } & Pemeliharaan (Rearing) \\
\hline 29 September 2012 & Muara sungai Donan & Kutawaru, Cilacap \\
September $29^{\text {th }} 2012$ & Donan river estuarine & \\
21 Oktober 2012 & Bendung Gerak Serayu & Kebasen, Banyumas \\
October $21^{\text {st }} 2012$ & Serayu flexibel dam & \\
15 November 2012 & Kecamatan Adipala, Cilacap & Kemranjen, Banyumas \\
November $15^{\text {th }} 2012$ & Adipala subdistrict, Cilacap & \\
\hline
\end{tabular}




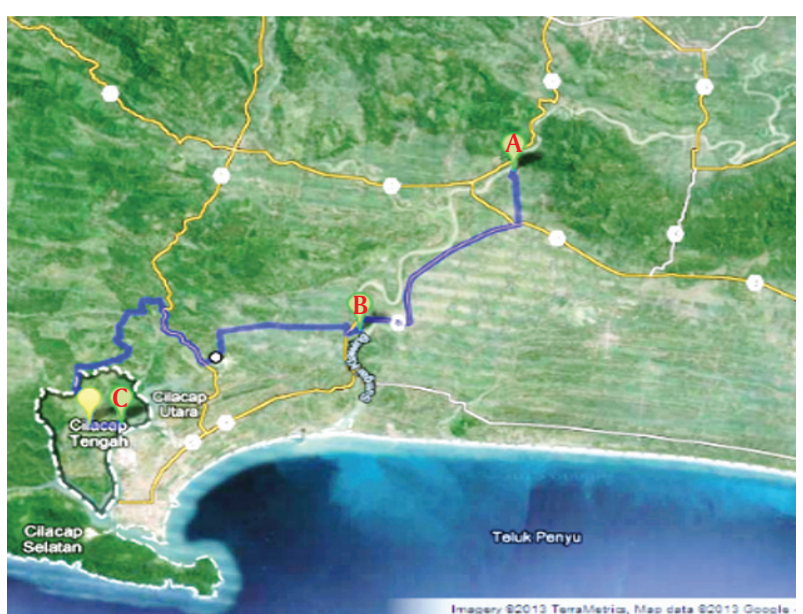

Gambar 1. Peta lokasi sampling (A: Bendung Gerak Serayu, B: Kecamatan Adipala, C: Sungai Donan)

Figure 1. Map shown sampling location (A: Serayu flexible dam, B: Adipala Subdistrict, C: Donan River)

Sampel dikumpulkan langsung dari nelayan penangkap dan pengepul benih ikan sidat kemudian diambil sebanyak 30 ekor per lokasi atau jika tidak mencukupi sebanyak 50\%-nya untuk pengamatan parameter status kesehatan secara langsung. Ikan sidat yang tersisa dipelihara dalam wadah yang telah disiapkan oleh pengepul selama 10 hari untuk kemudian diambil kembali dan diamati dengan prosedur yang sama seperti pengamatan sebelumnya.

\section{Persiapan dan Pengamatan Faktor Eksternal}

Sampel hasil tangkapan alam langsung ditempatkan pada akuarium berukuran $40 \mathrm{~cm}$ x $30 \mathrm{~cm}$ x $70 \mathrm{~cm}$ untuk pengamatan kondisi eksternal, pengukuran bobot, dan panjang. Kondisi eksternal yang diamati meliputi adanya luka dan kelainan lainnya.

\section{Pengamatan Parasit}

Keberadaaan parasit eksternal diamati dengan mengerok lendir dari seluruh tubuh ikan sidat, kemudian ditempatkan pada gelas objek dan ditetesi larutan fisiologis, ditutup dengan kaca penutup dan diamati menggunakan mikroskop binokuler pada perbesaran 400x. Hal serupa juga dilakukan dari lembaran insang. Ikan sidat kemudian dibedah dan dilakukan pengamatan parasit internal yang ada pada rongga tubuh dan saluran pencernaan. Pengamatan secara mikroskopis dilakukan dengan membuat ulasan dari isi saluran pencernaan (Haenen et al., 2010).

\section{Pemeriksaan Kondisi Hematologi}

Kondisi hematologis berupa total eritrosit dan leukosit serta diferensial leukosit diamati dengan preparat ulas darah dan pengecatan standar Giemsa dari sampel darah yang diambil melalui pangkal ekor (Haenen et al., 2010). Sebagai tambahan dilakukan pula pengukuran kadar hematokrit dengan menggunakan tabung mikro hematokrit untuk memperoleh gambaran adanya gangguan pada darah secara umum.

\section{Pengamatan Bakteri}

Pengamatan bakteri dilakukan dengan modifikasi metode yang dilakukan Esteve \& Alcaide (2009), yaitu membuat isolat dari organ yang luka atau mengalami nekrosis dan beberapa organ lain seperti hati, ginjal dan saluran pencernaan pada media Nutrient Agar (NA). Inkubasi dilakukan 1-3 hari pada suhu ruang. Setiap koloni yang tumbuh di-reisolasi hingga mendekati murni yang ditandai keseragaman warna dan bentuk. Identifikasi dilakukan berdasarkan morfologi koloni, sifat GRAM dan uji biokimia menggunakan kit API 20NE (Biomeureux (R).

\section{Histologi}

Gambaran histologis dari jaringan daging, hati, insang, ginjal, dan saluran pencernaan serta organ yang mengalami kerusakan atau terinfeksi patogen dibuat mengikuti metode dalam Abdelmonem et al. (2010), yaitu memotong jaringan pada ketebalan $5 \mu \mathrm{m}$, fiksasi dengan 10\% neutral buffered formalin (BNF) dan pewarnaan menggunakan hematoxylin dan eosin (H\&E). Pengamatan selanjutnya dilakukan dengan mikroskop binokuler pada perbesaran 400x.

\section{Analisis Data}

Parameter status kesehatan berupa kerusakan organ, prevalensi dan intensitas patogen, gambaran darah, dan gambaran histologis ikan sidat dianalisis secara diskriptif untuk menggambarkan adanya perubahan kondisi kesehatan sidat secara umum setelah pemeliharaan sementara.

\section{HASIL DAN BAHASAN}

Total 113 ekor ikan sidat diamati dalam penelitian ini terdiri atas 14 ekor dari Donan, 60 ekor dari Bendung Gerak Serayu, dan 39 ekor dari Adipala. Sejumlah 57 ekor dari total sampel diamati langsung setelah ditangkap dan 56 ekor sisanya diamati setelah pemeliharaan selama 10 hari oleh pengepul pada setiap lokasi (Tabel 2).

Gejala klinis yang ditunjukkan ikan sidat berupa bercak kemerahan pada bagian ekor, kepala dan badannya. Gejala tersebut dapat ditemukan pada sampel sebelum dan setelah pemeliharaan, namun lebih banyak pada sampel setelah pemeliharaan. Bercak kemerahan ini diduga terjadi akibat infeksi patogen, 
Tabel 2. Jumlah sampel serta bobot dan panjang ikan sidat (Anguilla sp.)

Table 2. Number of sample, weight and length of eel (Anguilla sp.)

\begin{tabular}{lccccc}
\hline $\begin{array}{c}\text { Lokasi sampel/pemeliharaan } \\
\text { Location of sampling and } \\
\text { rearing }\end{array}$ & $\begin{array}{c}\text { Jumlah sampel } \\
\text { Total sample }\end{array}$ & $\begin{array}{c}\text { Waktu } \\
\text { pengamatan } \\
\text { Observation time }\end{array}$ & $\begin{array}{c}\text { Bobot } \\
\text { Weight }(\mathbf{g})\end{array}$ & $\begin{array}{c}\text { Panjang } \\
\text { Length } \mathbf{( c m )}\end{array}$ & $\begin{array}{c}\text { Faktor kondisi } \\
\text { Condition factor }\end{array}$ \\
\hline Donan & 6 & A & $64,91 \pm 1,26$ & $46,82 \pm 1,56$ & $0,63 \pm 0,05$ \\
Kutawaru & 8 & B & $63,57 \pm 0,89$ & $45,39 \pm 0,87$ & $0,68 \pm 0,03$ \\
Bendung Gerak Serayu & 30 & A & $56,73 \pm 1,43$ & $40,07 \pm 1,03$ & $0,88 \pm 0,05$ \\
Serayu flexibel dam & 30 & B & $55,92 \pm 1,08$ & $39,86 \pm 1,03$ & $0,88 \pm 0,05$ \\
Kebasen & 21 & A & $59,12 \pm 0,84$ & $43,33 \pm 0,8$ & $0,73 \pm 0,03$ \\
Adipala & 18 & B & $60,72 \pm 0,67$ & $43,53 \pm 0,91$ & $0,74 \pm 0,04$ \\
Kemranjen & 113 & & & &
\end{tabular}

Keterangan (Note):

$\mathrm{A}=$ Pengamatan langsung setelah sampel ditangkap; $\mathrm{B}=$ Pengamatan sampel setelah pemeliharaan 10 hari di pengepul $(A=D i r e c t$ observation after catching; $B=$ Observation after 10 days rearing in traditional fisherman)
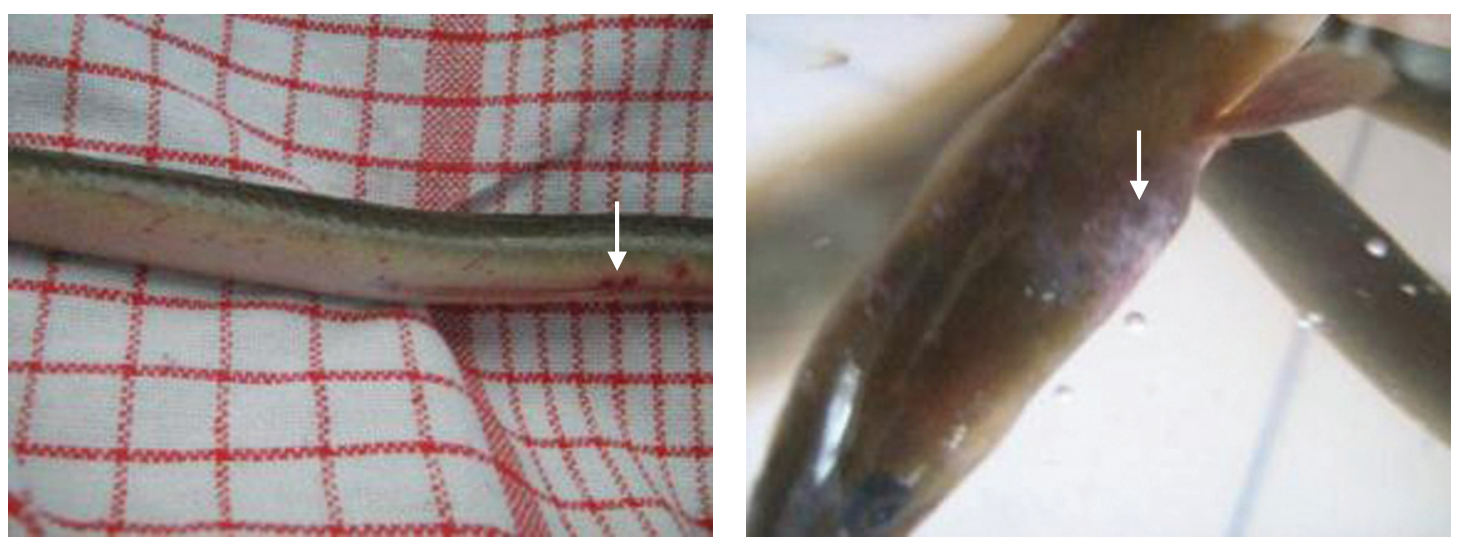

Gambar 2. Bercak kemerahan (ditunjukkan dengan tanda panah) pada tubuh ikan sidat

Figure 2. Reddish node (shown in arrow) of eel body

iritasi maupun luka karena bergesekan dengan sampel yang lain (Gambar 2).

Terdapat empat jenis parasit, yaitu golongan Nematoda (Camallanidae dan Anguillicoloides) yang menginfeksi organ internal tubuh dan Plathyhelminthes (Monogenea dan Digenea) yang menginfeksi insang (Tabel 3). Camallanidae (prevalensi 16,67\%; intensitas tiga parasit/individu) ditemukan hanya pada sampel setelah penangkapan dari muara Sungai Donan dan Anguillicoloides (prevalensi 5,56\%; intensitas dua parasit/individu) ditemukan hanya pada sampel dari pemeliharaan sementara di Kemranjen. Identifikasi Camallanidae pada ikan sidat pertama kali dilaporkan pada tahun 2004 oleh Moravec \& Justine (2006) pada ikan sidat Pasifik (Anguilla obscura) dengan prevalensi mencapai $51 \%$ dan intensitas $1-25$ parasit/ individu, pada Anguilla bicolor dengan prevalensi 1-13\% dan intensitas 1-25 parasit/individu (Moravec et al., 2006). Jenis Anguillicoloides juga baru dilaporkan menyebabkan gangguan serius pada budidaya ikan sidat secara intensif di Jepang (Moravec et al., 2005) dan Taiwan (Murderle et al., 2006). Namun demikian, infeksi Anguillicoloides sangat banyak dilaporkan terjadi pada ikan sidat Eropa dengan rata-rata prevalensi 3,7\%-86,0\% per tahun dan intensitas 4,0-12,6 parasit per individu dalam kurun waktu 1992-2008 (Kangur et al., 2008). Adanya kedua jenis parasit ini pada sampel yang diamati menunjukkan bahwa keduanya berpotensi mengganggu pertumbuhan ikan sidat di Indonesia.

Monogenea dan Digenea dalam penelitian ini ditemukan pada sampel sebelum dan setelah pemeliharaan sementara, dengan Monogenea lebih sering ditemukan. Prevalensi dan intensitas tertinggi untuk Monogenea pada sampel sebelum pemeliharaan adalah 9,52\%; dua parasit/individu (Kecamatan Adipala) dan setelah pemeliharaan 25\%; satu parasit/individu (Kutawaru). Sementara itu, prevalensi dan intensitas 
Digenea sebelum pemeliharaan adalah $4,76 \%$; satu parasit/individu (sampel dari Kecamatan Adipala) dan setelah pemeliharaan $6,67 \%$; satu parasit/individu (sampel dari Kebasen). Aguillar et al. (2005) menyebutkan bahwa prevalensi monogenean pada sidat dapat mencapai 61,5\% dengan intensitas 1-644 parasit/individu dan Digenea dapat mencapai prevalensi hingga 18,27\% dengan intensitas 1-31 parasit/individu. Hasil penelitian ini menunjukkan bahwa secara umum tidak ada perubahan besar pada komposisi, prevalensi dan intensitas parasit pada sampel yang diamati. Namun demikian, potensi kerugian budidaya akibat adanya patogen tersebut harus menjadi perhatian tersendiri.

Hasil identifikasi bakteri dalam penelitian ini terdiri atas Aeromonas hydrophylla, Pseudomonas luteola, Vibrio fluvialis, Aeromonas sobria, dan Aeromonas caviae (Tabel 3). Bercak berwarna kemerahan merupakan ciri umum pada sampel yang terinfeksi bakteri (Gambar 2). Kelompok sampel sebelum pemeliharaan terinfeksi oleh P. luteola, V. fluvialis, dan A. hydrophylla dengan organ terinfeksi hati dan ginjal. Kelompok sampel setelah pemeliharaan terinfeksi oleh $V$. fluvialis, $A$. sobria, dan $A$. caviae dengan organ terinfeksi saluran pencernaan, hati dan insang. Kelompok bakteri aeromonid (A. hydrophyla, A. sobria, dan A. caviae) merupakan jenis yang paling banyak menginfeksi karena bakteri ini sangat menyukai perairan kaya bahan organik seperti jalur migrasi ikan sidat. Zeng et al. (2010) menyebutkan bahwa sebagian besar bakteri yang menginfeksi ikan sidat adalah dari kelompok aeromonas dengan persentase mencapai 48,9\% dalam analisis filogenetik. Hal ini dapat dimengerti karena kelompok ini mampu hidup pada rentang perairan luas dengan batas salinitas hingga $15 \mathrm{mg} / \mathrm{L}$ (Camus et al., 1998).

Bakteri V. fluvialis dan P. luteola sebenarnya juga masih dalam kelas sama dengan ketiga jenis bakteri sebelumnya, yaitu Gamma Proteobakteria. Namun demikian, P. luteola lebih banyak ditemukan dalam perairan tercemar logam berat, sedangkan $V$. fluvialis dalam perairan dengan kecenderungan memiliki salinitas tinggi (Zeng et al., 2010). Kedua jenis bakteri ini didapatkan pada sampel dari muara Sungai Donan dan Kutawaru yang merupakan daerah di dekat kawasan industri di Kabupaten Cilacap. Pemeliharaan selama 10 hari oleh pengepul tidak memberikan pengaruh besar pada pertumbuhan bakteri, namun adanya luka akibat gesekan selama pemeliharaan dapat memperbesar peluang meningkatnya infeksi bakteri.

Perubahan kondisi fisiologis ikan sidat setelah pemeliharaan sementara dapat diamati pada peningkatan level hematokrit, jumlah total sel darah putih dan jumlah total sel darah merah (Tabel 4). Level hematokrit meningkat dari $38,49 \pm 4,23 \%$ pada kondisi awal tertangkap menjadi $41,79 \pm 4,76 \%$ setelah pemeliharaan, jumlah total sel darah putih (x10 $\mathrm{sel} / \mathrm{mL}$ ) dari $1,93 \pm 1,03$ menjadi $2,17 \pm 1,14$ dan jumlah total sel darah merah $\left(\mathrm{x} 10^{6} \mathrm{sel} / \mathrm{mL}\right)$ berubah dari $1,57 \pm 0,27$ menjadi $1,61 \pm 0,83$. Perubahan ketiga parameter fisiologis pada ikan sidat tersebut masih dapat digolongkan dalam batas normal, sebagaimana dilaporkan oleh (Dikic et al., 2013). Laporan tersebut menyebutkan bahwa Anguilla anguilla memiliki kisaran nilai beberapa parameter fisiologis yang lebih beragam dibandingkan Conger conger dan Muraena helena (jenis sidat yang hidup di dalam laut) yaitu hematokrit $37,76 \pm 4,62 \%$; total sel darah putih 2,21 $\pm 1,39\left(\times 10^{4} \mathrm{sel} / \mathrm{mL}\right)$ dan total sel darah merah $1,61 \pm 0,73\left(\times 10^{6} \mathrm{sel} / \mathrm{mL}\right)$. Perbedaan ini disebabkan karena kondisi lingkungan $A$. anguilla lebih beragam dibandingkan kedua jenis sidat tersebut. Oleh karena itu, perubahan kondisi fisiologis pada sidat setelah pemeliharaan sementara diduga kuat terjadi karena adanya pengaruh tekanan lingkungan akibat ketiadaan pergantian air, ketiadaan pemberian pakan, dan penyimpanan dalam kepadatan tinggi.

Komposisi sel darah putih pada ikan sidat mengalami sedikit perubahan pasca pemeliharaan sementara selama 10 hari oleh pengepul. Limfosit (\%) turun dari $60,42 \pm 3,19$ menjadi $57,62 \pm 3,02$, granulosit naik dari 35,18 $\pm 4,42$ menjadi $36,51 \pm 2,11$ dan monosit turun dari 4,28 $\pm 1,91$ menjadi $3,85 \pm 2,03$ (Tabel 4). Sel darah putih kelompok granulosit berperan dalam penanggulangan serangan patogen. Limfosit merupakan jenis sel darah putih yang bertanggung jawab terhadap imunitas dari adanya mikroorganisme dan makromolekul asing di dalam tubuh. Peningkatan granulosit terjadi karena adanya luka selama pemeliharaan sehingga sel ini dibutuhkan dalam jumlah besar untuk menangkal infeksi mikroorganisme dan antigen lain yang mungkin menyusup ke dalam tubuh ikan sidat. Monosit berperan sebagai prekursor sistem fagosit. Bersama limfosit, monosit mengambil peran penting ketika ada infeksi mikroorganisme ke dalam tubuh. Penurunan limfosit dan granulosit dimungkinkan terjadi karena tidak adanya peningkatan infeksi dari patogen yang ada. Kondisi serupa juga ditunjukkan oleh Monopterus albus sebelum dan setelah budidaya, di mana monosit turun dari $10,96 \pm 2,25 \%$ menjadi $10,08 \pm 1,58 \%$ dan neutrofil sebagai perwakilan kelompok granulosit meningkat dari 11,69 $\pm 1,69 \%$ menjadi $11,85 \pm 10,25 \%$ (Ponsen et al., 2009).

Gambaran histologis organ dari ikan sidat setelah pemeliharaan sementara juga menunjukkan adanya beberapa kelainan yaitu adanya hiperplasia pada insang (Gambar 3), nekrosis dan inflamasi pada hati (Gambar 4) serta nekrosis dan lesi pada otot tubuh (Gambar 5). 


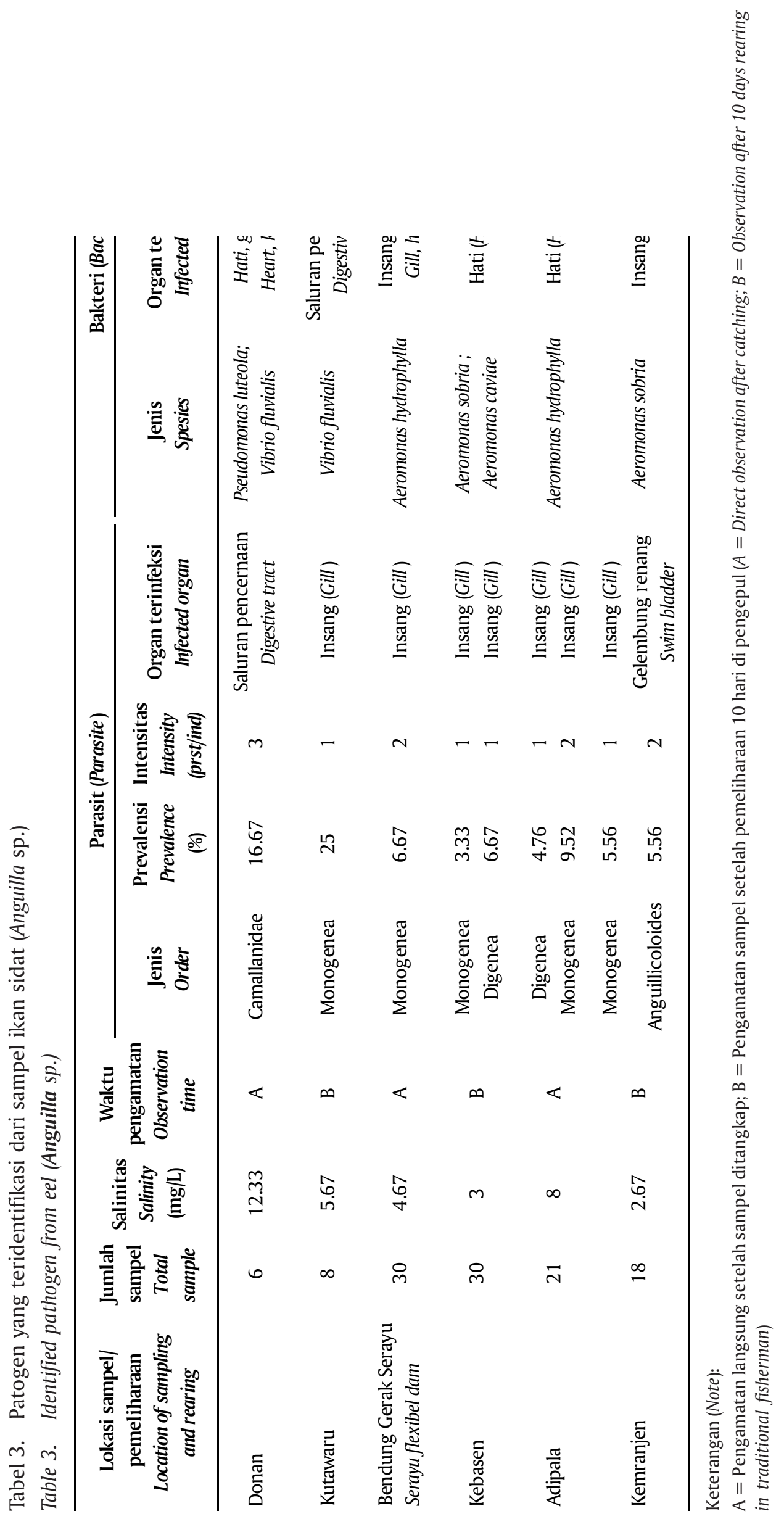


Tabel 4. Kondisi hematologis sampel ikan sidat

Table 4. Eel haematologycal condition

\begin{tabular}{lcc}
\hline \multirow{2}{*}{ Parameter (Parameter) } & \multicolumn{2}{c}{ Sampel (Sample) } \\
\cline { 2 - 3 } & Penangkapan (Catching) & Pemeliharaan (Rearing) \\
\hline Hematokrit (Haematocrit) $(\%)$ & $38.49 \pm 4.23$ & $41.79 \pm 4.76$ \\
Total sel darah putih $\left(\mathrm{x} 10^{4} \mathrm{sel} / \mathrm{mL}\right)$ & $1.93 \pm 1.03$ & $2.17 \pm 1.14$ \\
Total white blood count $\left(\times 10^{4} \mathrm{cells} / \mathrm{mL}\right)$ & & \\
Total sel darah merah $\left(\times 10^{6} \mathrm{sel} / \mathrm{mL}\right)$ & $1.57 \pm 0.27$ & $1.61 \pm 0.83$ \\
Total red blood count $\left(\times 10^{6} \mathrm{cells} / \mathrm{mL}\right)$ & $60.42 \pm 3.19$ & $57.62 \pm 3.02$ \\
Limfosit (Limfocyt) $(\%)$ & $35.18 \pm 4.42$ & $36.51 \pm 2.11$ \\
Granulosit (Granulocyt) $(\%)$ & $4.28 \pm 1.91$ & $3.85 \pm 2.03$ \\
Monosit (Monocyt) $(\%)$ & & \\
\hline
\end{tabular}

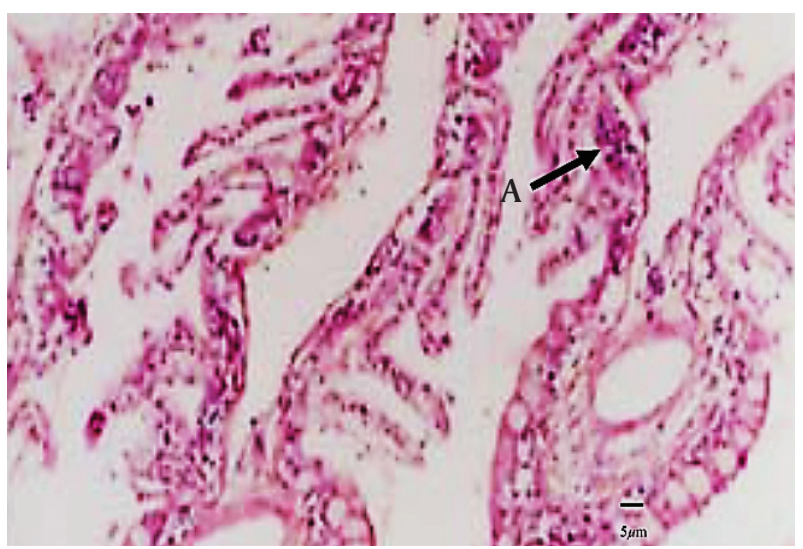

Gambar 3. Histologi insang ikan sidat yang mengalami hiperplasia (A)

Figure 3. Gill histology of eel shown hyperplasia (A)

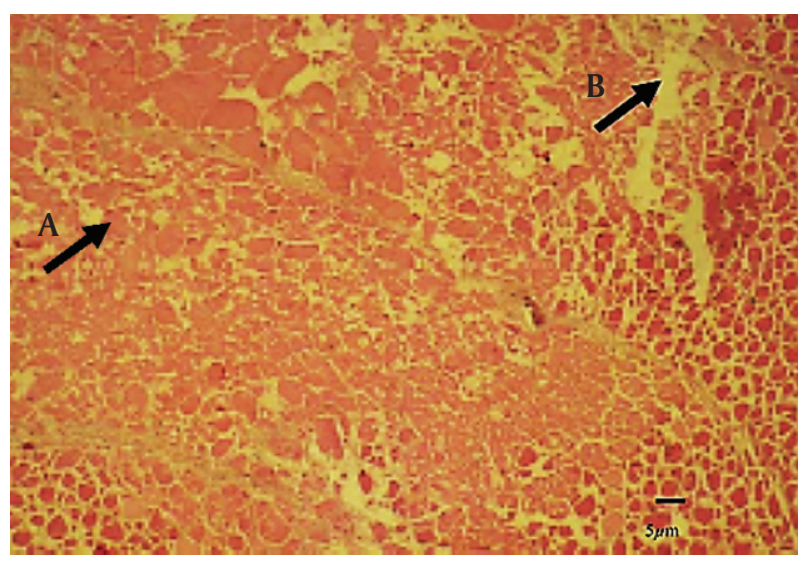

Gambar 5. Histologi otot ikan sidat yang mengalami nekrosis (A) dan lesi (B)

Figure 5. Muscle histology of eel shown necrosis (A) and lesion (B)

Hiperplasia merupakan suatu keadaan di mana sel-sel berkembang dalam jumlah berlebihan. Kondisi ini dipicu oleh berbagai hal termasuk adanya in-

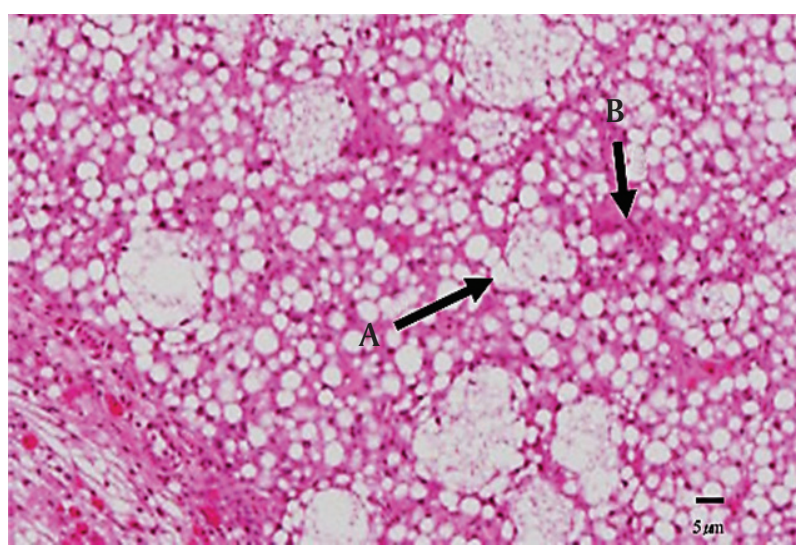

Gambar 4. Histologi hati sidat yang mengalami nekrosis (A) dan inflamasi (B)

Figure 4. Hepar histology of eel shown necrosis (A) and inflamation (B)

feksi patogen. Adanya infeksi monogenea dan A. sobria yang memanfaatkan sel-sel insang sebagai bahan makanan dari sampel sidat dalam penelitian ini diduga merupakan salah satu faktor penyebab terjadinya proliferasi sel dalam jumlah berlebihan tersebut. Hiperplasia pada insang sidat pernah dilaporkan terjadi pada Anguilla japonicus dan Anguilla anguilla akibat infeksi bakteri dari kelas gammaproteobacteria dan mengakibatkan penurunan kemampuan jantung untuk memompa darah, penumpukan mukus dalam jumlah berlebihan sehingga menganggu pernafasan dan pada infeksi serius dapat terjadi kerusakan insang secara merata. Hiperplasia tersebut kemudian akan diikuti dengan nekrosis sel dan pada akhirnya mematikan seluruh sel pada insang (Bullock, 1990).

Nekrosis dan inflamasi pada hati lebih banyak disebabkan oleh adanya infeksi bakteri. Inflamasi yang kemudian diikuti dengan nekrosis dan lesi merupakan tanda umum infeksi bakteri aeromonid. Jenis bakteri ini menyerang inangnya secara sistemik dengan memanfaatkan peredaran darah sehingga akan sangat 
mudah ditemukan pada organ seperti hati dan ginjal. Adanya nekrosis di hati, dipastikan karena sel-sel telah mengalami kerusakan akibat adanya infeksi patogen, namun inflamasi bisa jadi merupakan mekanisme pertahanan tubuh untuk mengisolasi infeksi patogen tersebut.

Nekrosis dan lesi yang terjadi pada otot tubuh dapat disebabkan oleh adanya infeksi patogen dari jenis parasit yang dalam mekanisme infeksinya melekatkan diri dengan cara menusukkan alat pengaitnya pada jaringan kulit. Kondisi ini akan menyebabkan sel-sel otot mengalami kerusakan dan pada infeksi serius dapat menyebabkan terjadinya lesi yang kemudian akan berkembang menjadi luka terbuka. Abdelmonem et al. (2010) menyebutkan bahwa di samping akibat mekanisme penempelan secara fisik, nekrosis pada jaringan tubuh dapat pula terjadi karena infiltrasi larva beberapa jenis parasit yang berkembang biak pada saat menginfeksi. Selain infeksi parasit, infeksi bakteri juga dapat menyebabkan terjadinya nekrosis akibat sel-sel yang mati karena faktor virulensi bakteri tersebut.

Terjadinya perubahan pada kondisi fisiologis ikan sidat setelah pemeliharaan sementara menunjukkan bahwa metode yang digunakan untuk menampung ikan sidat sebelum digunakan untuk budidaya harus diperbaiki. Hal ini dapat menentukan keberhasilan usaha pembudidayaan (pembesaran) ikan sidat karena benih ikan sidat yang sehat akan memiliki ketahanan hidup dan kecepatan pertumbuhan yang lebih baik. Adanya beberapa jenis patogen dari golongan parasit dan bakteri juga harus diperhatikan karena pemeliharaan yang kurang baik dapat menyebabkan tingkat infeksi patogen tersebut meningkat. Ditemukannya parasit dari famili Anguillicoloides (Nematoda) merupakan kejadian yang pertama kali dilaporkan dari ikan sidat di Indonesia. Parasit ini harus mendapatkan perhatian lebih karena telah menjadi masalah paling besar bagi budidaya sidat di Eropa.

\section{KESIMPULAN DAN SARAN}

Pemeliharaan sementara selama 10 hari oleh pengepul tidak memberikan perubahan besar pada status kesehatan ikan sidat. Perubahan pada kondisi hematologi dan histopatologi mengindikasikan bahwa pemeliharaan tersebut berpotensi menyebabkan gangguan dalam jangka panjang. Penambahan rentang sampel yang meliputi jumlah, diferensiasi ukuran, lokasi dan waktu sampling perlu dilakukan mengingat pola migrasi sidat yang terkait dengan musim, jalur migrasi dan melibatkan banyak ukuran berbeda. Keseluruhan data tersebut dapat diolah untuk menemukan model dalam kajian epidemiologi tentang status kesehatan ikan sidat di Indonesia.

\section{DAFTAR ACUAN}

Abdelmonem, A.A., Metwally, M.M., Hussein, H.S., \& Elsheikha, H.M. (2010). Gross and microscopic pathological changes associated with parasitic infection in European eel (Anguilla anguilla, Linnaeus 1758). Parasitol Res., 106, 463-469.

Aguilar, A., Alvarez, M.F., Leiro, J.M., \& Sanmartýn, M.L. (2005). Parasite populations of the european eel (Anguilla anguilla L.) in the rivers Ulla and Tea (Galicia, northwest Spain). Aquaculture, 249, 8594.

Briones, A.A., Yambot, A.V., Shiao, J.C., lizuka, Y., \& Tzeng, W.N. (2007). Migratory pattern and habitat use of tropical eels Anguilla spp. (Teleostei: Anguilliformes: Anguillidae) in Phillipines, as revealed by otolith microchemistry. The Raffles Bulletin of Zoology, 14, 141-149.

Bullock. (1990). Bacterial gill disease of freshwater fishes. Fish Disease Leaflet, 84, 1-17.

Camus, A.C., Durborow, R.M., Hemstreet, W.G., Thune, R.L., \& Hawke J.P. (1998). Aeromonas bacterial infections-motile aeromonad septicemia. SRAC Publication No. 478.

Dias, SCAC. (2010). Ecology and trophic dynamics of the European eel, Anguilla anguilla (L.) [Tesis]. Porto (POR): Universidade Do Porto.

Dikic, D., Lusicic, D., Skoko, S.M., Tutman, P., Skaramuca, D., Franic, Z., \& Skaramuca, B. (2013). Comparative hematology of wild Anguilliformes (Muraena helena, L. 1758, Conger conger, L. 1758 and Anguilla anguilla L. 1758). Animal Biology, 63, 77-92.

Esteve, C., \& Alcaide, E. (2009). Influence of diseases on the wild eel stock: the case of Albufera Lake. Aquaculture, 289, 143-149.

Froese, R. (2006). Cube law, condition factor and weight-length relationships: history, meta-analysis and recommendations, J. Appl. Ichthyol., 22, 241-250.

Haenen, O.L.M., Lehmann, J., Engelsma, M.Y., Stürenberg, F.J., Roozenburg, I., Kerkhoff, S., \& Breteler, J.K. (2010). The health status of european silver eels, Anguilla anguilla, in the Dutch River Rhine Watershed and Lake Ijsselmeer. Aquaculture, 309, 15-24.

Kangur, A., Kangur, P., Kangur, K., Jarvalt, A., \& Haldna, M. (2008). Anguillicoloides crassus infection of european eel, Anguilla anguilla (L.), in inland waters of Estonia: history of introduction, prevalence and intensity. J. Appl. Ichthyol. 26 (Suppl. 2), 74-80.

Moravec, F., \& Justine, J.L. (2006). Camallanus cotti (Nematoda: Camallanidae), an introduced parasite 
of fishes in New Caledonia. Folia Parasitologica, 53, 287-296.

Moravec, F., Nagasawa, K., \& Miyakawa, M. (2005). First record of ostracods as natural intermediate hosts of Anguillicola crassus, a pathogenic swimbladder parasite of eels Anguilla spp. Diseases of Aquatic Organism, 66, 171-173.

Moravec, F., Taraschewski, H., Anantaphruti, M.T., Maipanich, W., \& Laoprasert, T. (2006). Procamallanus (Spirocamallanus) Anguillae sp. N. (Camallanidae) and some other nematodes from the Indonesian shortfin eel Anguilla bicolor in Thailand. Springer-Verlag online Published: 24 June 2006.

Münderle, M., Taraschewski, H., Klar, B., Chang, C.W., Shiao, J.C., Shen, K.N., He, J.T., Lin, S.H, \& Tzeng, W.N. (2006). Occurrence of Anguillicola crassus (Nematoda: Dracunculoidea) in Japanese eels Anguilla japonica from a river and an aquaculture unit in SW Taiwan. Diseases of Aquatic Organism, 71, 101-108.

Palstra, A.P., Heppener, D.F.M., Ginneken, V.J.T.V., Székely, C., \& Thillart, G.E.E.J.M.V.D. (2007). Swimming performance of silver eels is severely impaired by the swim-bladder parasite Anguillicola crassus. Journal of Experimental Marine Biology and Ecology, 352, 244-256.

Pedersen, K., Skall, H.F., Nielsen, A.M.L., Nielsen, T.F., Henriksen, N.H., \& Olesen, N.J. (2008). Surveillance of health status on eight marine rainbow trout, Oncorhynchus mykiss (Walbaum), farms in Denmark in 2006. Journal of Fish Diseases, 31, 659667.

Ponsen, S., Narkkong, N.A., Pamok, S., \& Aengwanich, W. (2009). Comparative hematological values, morphometric and morphological observation of the blood cell in capture and culture asian Eel, Monopterus albus (Zuiew). American Journal of Animal and Veterinary Sciences, 4(2), 32-36.

Rodriguez, A., Gisbert, E., Rodriguez, G., \& Orvay, F.C. (2005). Histopathological observations in European glass eels (Anguilla anguilla) reared under different diets and salinities. Aquaculture, 244, 203214.

Zeng, Y., Ma, Y., Wei, C., Jiao, N., Tang, K., Wu, Z., \& Jian, J. (2010). Bacterial diversity in various coastal mariculture ponds in southeast China and in diseased eels as revealed by culture and culture-independent molecular techniques. Aquaculture Research, 41, 172-186. 